\title{
Imidazol(glyoxaline) 誘導體に關する研究(第一報)
}

\author{
4. or 5-Methylimidazol (4 or 5-methylglyoxaline) \\ の製法に就て
}

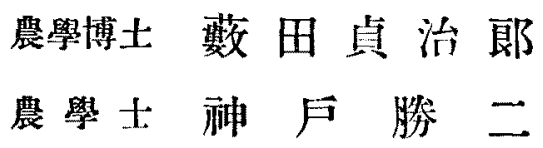

(炤和二年十二月九日受理)

Glucose が稀薄アルカソの作用により Oxy-acid 例へば乳酸を生ずるこをは古 くさり知られたる事實な ${ }^{(1)(2)(3)}$ Windaus und Knoop ${ }^{(4)}$ は若し其際アンモニャを 用ひなばえに相當するアミノ酸例入ば Alanineの如きと生ぜざるやを試みしに陰 性の結果を得たれごもZinc hydroxyde ammonia（又は节性加里こアンモニャ)を 冷處に於て作用せしめたるに多量の Methylimidazol を生ずるこご見出せりかく の如く炭水化物ょり生物界に廣く分布せる Imidazol 誘導體の生ずるここは興味 おる發見こ称すへし

Glucoseより如何にしてアンモニヤの作用によりGlyoxalineが生ずるかはGlucose より乳酸の生成に關する Pinkus, ${ }^{(5)} \mathrm{Nef}^{(6)}$ Wohl $^{(7)}$ 及び Buchner ${ }^{(8)}$ 等の想像せる 如くGlucose が先つ Glycerine aldehydeに分解し分子內軠移により Methylglyoxal となり乳酸に變ずるものと考ふれば Methylglyoxaline はこの Methylglyoxal が o-Dicarbonyl 化合體より Glyoxaline の锫知生成法に從ひ Formaldehyde 及びア ンモニヤと縮合するここにより作られ得べし

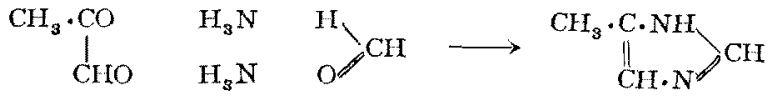

此反㮣に與る Formaldehyde は Glycerine aldehydeの分解により生し得心し

$$
\mathrm{CH}_{2} \mathrm{OH} \cdot \mathrm{CHOH} \cdot \mathrm{CHO} \longrightarrow \mathrm{CH}_{3} \mathrm{COOH}+\mathrm{HCHO}
$$

Methyl glyoxaline の結晶は甚だ吸䈘性にして水アルコールに易溶なれごもエ ーラルには戴溶にして融點 $56^{\circ} \mathrm{C} な る$

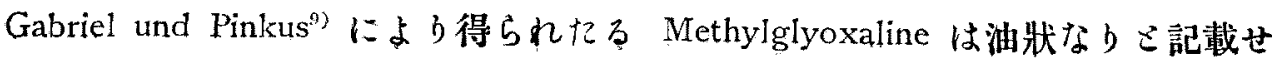


られてれごも Jowett und Potter ${ }^{(10)}$ は之を結晶狀に得て融點 $55^{\circ}$ なりこ報告せ b Chlorplatinate $\left(\mathrm{C}_{4} \mathrm{H}_{6} \mathrm{~N}_{2}\right)_{2} \mathrm{H}_{2} \mathrm{PtCl}_{6}$ の融點は $206^{\circ} に し て$ Picrate $\mathrm{C}_{4} \mathrm{H}_{6} \mathrm{~N}_{2} \cdot \mathrm{C}_{6} \mathrm{H}_{3} \mathrm{~N}_{3} \mathrm{O}_{7}$ の融點は 159ー160な

Windaus ${ }^{(11)}$ は叉 Acetaldehyde の存在に於て Glucose te Zinc hydroxyde ammonia にて分解して 2,5-Dimethyl imidazol を分離せり

著者等は Glyoxaline 誘導體を研究するに際しその材料となるべき Methylglyoxaline を多量に且つ容易に得らるべき方法を求むるに上述の Windaus 氏法に伐 るを最も容易なりこすれども售數週に亘る長時日を要し多量に製せんこするには 不便の點少から声故に著者等は反應時間を短縮し操作を簡易ならしむ心゙く研究せ

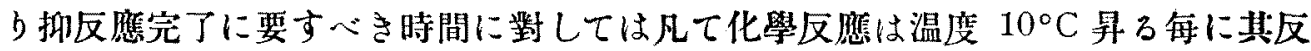
應速度は倍加するものなればこの Glucose のアンモニャによる分解及び分解後の 縮合反㤫に於て温度の上年により他の複雑なる副反應起らざる限り時間は短縮し 得へければ種々の温度にて試驗せるに果して温度の上昇さ共に液の着色著しく且 つ沈澱の生ずること速やかにして多量さなり温度 50-60前後最適にして時間は 1-2 日にて反應略完了するを知れり温度之上り高くなれば收量炏第に減じ浴温 $100^{\circ}$ こなれば反應速やかに過ざ液は黑褐色こなりて多量の樹脂狀物質を生し結果 不良なり

上記の反應に際し溶液に (1) $\mathrm{NaOH},(2)$ Formalin, (3) Formalin + $\mathrm{NaOH}$ を添加し反㮣の促進收量の增加の有無を檢せるに其影響なきを認めたり

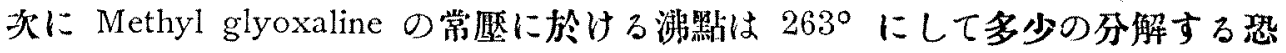
あるも減壓の下に行へば分解するこをなく蒸溜するを確め得さる故に亞鉛監より 亞鉛走硫化水素にて除去せる液を濃縮し直ちに劃温蒸溜せるに $4 \mathrm{~mm} .142^{\circ} \mathrm{C} に \tau$ 微黄色粘稠なる液を溜出し初妙出中は $144-146^{\circ}$ を保持す溜出液は暫時にして 聚落せる塊狀に全部固化す吸濕性の結晶にして融點 $56^{\circ}$. Windaus 氏の Oxalate より純䅴にせるものこ同一融點にして單なる蒸溜による容易に純物質を得るを知 れり種々の誘導體を作りてその同一なるこをを確め收量の點に於ても蒸溜法によ るものの常こして多少の損失は免れざれごもその損失量は僅かにして上記の處理 法は時間及び操作の上に一段の改良をなし得てるすのこ云い得へし

\section{實 驗之 部}

A) Methyl glyoxaline zinc salt $の$ 製法 


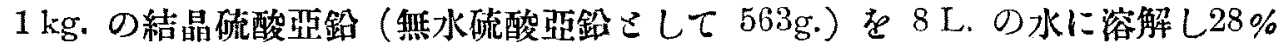
$P モ=ヤ$ 水 425 c.c. を加へて水酸化亞鉛の白色沛澱を生せしむ初めは之を傾湶法

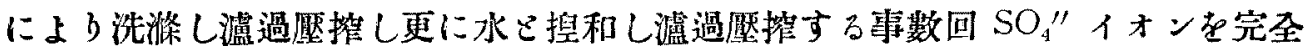

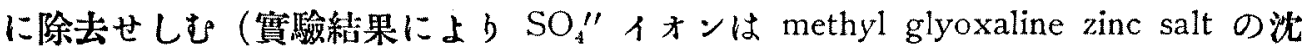
澱するを妨ぐるを知ればなり）允分壓挨して可及的に水分を除去せる水酸化亞制 の沈澱に直ちに28\%アンモニヤ水 $2 \mathrm{~L}$. を加ふれば殆んぎ無色の透明溶液さな る之に市販の粗製葡䓒糖 $1.35 \mathrm{~kg} .(74 \%$ の無水葡萄糖を含み純品約 $1 \mathrm{~kg}$. に相 當す）を加へ密栓してょく振盪すれば淡黄褐色透明溶液さなるべし

其溶液を稍壓に耐ゆる瓶に入れゴム栓にて密栓し 50 - $60^{\circ}$ の水浴上に放置せ るに眬に 1 恃間後に液は濃褐色に變じ且つ多量の沈澱を生し其狀態室温に2-3日 放置せるものに相當せり其後時々少量の上澄液を試驗管に分ち取り $50-60^{\circ}$ に保 ち時間の經過に件ひ更に洗溉生成の有無により反應の完否检せるに約 2 書夜の 後反歪略完結せるを認めたるが故に Buchner funnel 上に沈澱を集め之を素燒板 上にて乾燥せるに $320 \mathrm{~g}$, $100^{\circ}$ の乾噪器中にて乾燥せるに $195 \mathrm{~g}$.となりWindaus 氏法によるものを收量略同じ

倘沈筂を分離せる母液を放置或は加温すれば更に少量の亞鉛監の沈澱を生ず

(B) Methyl glyoxaline $の$ 製法

かくして得たる沈澱は之を温水に浮游せしめて硫化水素を通し硫化亞鉛を沈澱 せしめて瀘過壓搾し尙硫化亞鉛の沈澱は數回温水にて洗涤し瀘液は全部合して減 㻺蒸溜により濃縮し半部は Windaus の方法に從ひェーテルにて浸出し浸出液は 蓚酸のエーラル溶液を加へて Oxalate こなし $75 \%$ Acetoneにて再結するに無色

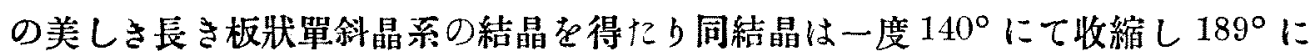
て泡を發して融解すこれ乾燥して無水物こなせるものつ融點は206なり

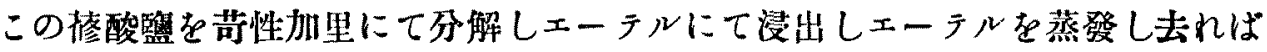
無色油狀物質となり放置するここにより次第に聚落狀の結晶を析出す乾燥せるも ○〉融點は $56^{\circ} な ら$

次に濃縮液の殘半分は減壓蒸溜にて完全に水分を除き直ちに劃温蒸溜を行ふに $4 \mathrm{~mm} .100^{\circ}$ 附近にて少量の微黃色液溜出し次に $142^{\circ}$ に至つて粘稠なる带黄色 液溜出し始め $144-146^{\circ}$ の間に全部蒸溜せらるコルベン中の残渣は固化せる炭化 物質なり 
溜出液は啠洔にして塊狀の聚落生長 (遂に全部固化す顯微鏡下にて微細なる針 狀結晶なり融點 $56^{\circ}$ 收量前者は $65 \mathrm{~g}$. にして後者は $60 \mathrm{~g}$. なり

炎に Methyl glyoxaline の亞鉛鹽を硫化水素にて分解する代っに $\mathrm{CO}_{2}$ 专用ひ

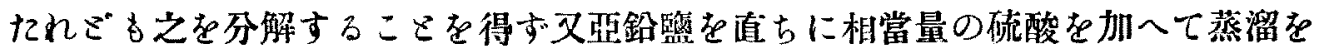
試みれれごも之も不成功に終れり

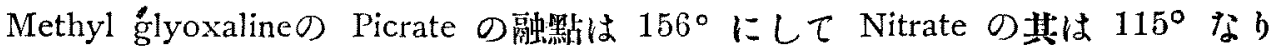

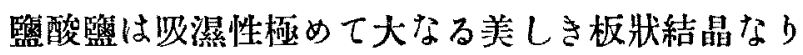

Picrate の分析

$$
\text { 物筫 } \begin{array}{rrr}
0.0329 \mathrm{~g} . & 23^{\circ} \mathrm{C} . & 759 \mathrm{~mm} . \quad \begin{array}{r}
6.65 \mathrm{c} . \mathrm{c} . \\
\mathrm{N}=22.63 \%
\end{array} \\
\mathrm{C}_{4} \mathrm{H}_{6} \mathrm{~N}_{2} \cdot \mathrm{C}_{6} \mathrm{H}_{3} \mathrm{~N}_{3} \mathrm{O}_{7} \text { として } \mathrm{N}=22.51 \%
\end{array}
$$

總括

Windaus und Knoop の發見に加〉る Glucose より Zinc hydroxyde ammonia の作用に上り Methylimidazol の製法に關しその分解縮合に加熱して反應を促進 せしめ且蒸溜法により之を分踓精製する著者等の考案せる改良法に就き報告す

\section{引用 文 献}

(1) Hoppe Seyler : Ber. 4, 346 (1871)

(2) Schützenberger: Bull. Soc. Chim. (2) 25, 289.

(3) Nencki und Sieber : Journ. fuir prakt, chem. [2] 24, 498 (1881)

(4) Windaus und Knocp: Ber. 38, 1166 (1905)

(5) Pinkus : Ber. 31, 32 (1898)

(6) J. V. Nef : Ann. d. chem. 335, 254, 279 (1904)

(7) Wohl : Lippmann, Chemie der Zuckerarten, (1904) 1891.

(8) Buchner: Ber. 38, 621 (1905)

(9) Gabriel und Pinkus : Ber. 26, 2205 (1893)

(10) Jowett und Potter: Journ. chem. Scc. 83, 464.

(11) Windaus : Ber. 39, 3886 (1906) 